\title{
Evaluation of Twenty Barley Genotypes For Drought Tolerance Under Sandy Clay Soil
}

\author{
F.F.B. Abu-El-Lail ${ }^{\#}$, K.A. Hamam ${ }^{*}$, K.A. Kheiralla ${ }^{* * *}$ and \\ M.Z. El-Hifny ${ }^{* *}$ \\ Breeding and Genetics Dept., Sugar Crops Research Institute, \\ ARC, Giza; *Agronomy Dept., Faculty of Agriculture, Sohag \\ University, Sohag and **Agronomy Dept., Faculty of \\ Agriculture, Assiut University, Assiut, Egypt.
}

\begin{abstract}
7 HIS RESEARCH was conducted in order to identify the best barley genotypes that can be grown under drought stress conditions. This experiment was conducted in a randomized complete block design with three replications at the Agriculture Experimental Research Farm of the Faculty of Agriculture, Sohag University, during the 2006 to 2008 seasons. Twenty barley genotypes (covered, 2-rowed) and the two check cultivars Giza 127 and Giza 128 were evaluated for drought tolerance by measuring yield performance under three levels of irrigation (normal, moderately reduced and severely reduced). Drought stress reduced grain yield ( $\operatorname{ardab} / \mathrm{fad})$ by reducing the number of spikes $/ \mathrm{m}^{2}$, the number of kernels/spike and 1000-kernel weight. This study showed that, the best genotypes of barley for all parameters studied under severe drought conditions were No. 17, No. 7 and No.13. The drought susceptibility index (DSI) of grain yield (ardab/fad) showed that nine genotypes had a (DSI) $<1$ and were relatively tolerant to drought stress. The results revealed that the reduction in grain yield for the highest genotype, (No. 17) and the lowest one, (No.9) due to drought increase was 22.66 and $26.28 \%$, respectively, with a general mean of $(28.82+1.35)$.
\end{abstract}

Keywords: Barley, Hordeum vulgare, Drought, Grain yield, Drought susceptibility.

Barley (Hordeum vulgare L.) is a major source of food today for a large number of people living in the semi arid areas of the world. In addition, this crop is cultivated in Egypt mainly under drought conditions which are not suitable for wheat growth. The total production of barley in Egypt in 2012/2013 season was 1085984 ardab $\left(\operatorname{ardab}=120 \mathrm{~kg}\right.$ ) from 78679 faddan $\left(\right.$ faddan $=4200 \mathrm{~m}^{2}$ ) with an average grain yield of 13.80 (ard. /fad) (Bulletin of Agriculture Statistics, 2014). Drought stress is a major abiotic factor that limits agricultural production (Golbashy, 2010), more importantly in the rain-fed areas of the world. Drought stress affects 40 to $60 \%$ of the world's agricultural lands (Shahryari \& Mollasadeghi, 2011). Drought is the most significant constraint for crop production in the world; therefore, employing high-yielding cultivars tolerant to

\#Correspondence email: farrag_abuellail@yahoo.com 
drought is an effective approach to reduce its detrimental effects (Dorostkar et al., 2016). Under rain-fed conditions in Mahout, Egypt, drought stress in barley causes significant reduction in no. grains/spikes, 100-kernel weight and grain yield/plant, suggesting that 100- kernel weight is less sensitive to drought stress as compared to the other yield components (El-Shouny et al., 2015). Breeding for drought resistance is complicated by the lack of fast, reproducible screening techniques and the inability to routinely create defined and repeatable water stress conditions when a large amount of genotypes are to be evaluated efficiently (Ramirez \& Kelly, 1998). The objective of this study was to evaluate some barley genotypes for their tolerance to drought stress and for grain yield and its components, using defined, reproducible irrigation regimes.

\section{Materials and Methods}

Field experiments were carried out at the Agriculture Experimental Research Farm of the Faculty of Agriculture, Sohag University, during 2006-2007 and 2007-2008 seasons. Twenty doubled haploid lines of a backcross population between a wild barley accession from the Middle East (ISR 42-S) and a German barley cultivar (Scarlett) were tested ( Univ. Bonn, Dept. of Crops Science and Plant Breeding). Scarlett is a high yielding cultivar which has high quality malting characteristics; however, ISR $42-8$ is a wild barley accession from the Middle East. The experiments were laid out in a Randomized Complete Block Design with three replicates. Each plot was represented by six $3 \mathrm{~m}$ rows, $20 \mathrm{~cm}$ apart with $10 \mathrm{~cm}$ interarow spacing. Total area was $3.5 \mathrm{~m}^{2}$. The agriculture practices recommended for barley production were applied through the growing season under sandy clay soil (Table 1).

TABLE 1. The mechanical and chemical properties of soil.

\begin{tabular}{|l|c|c|}
\hline \multicolumn{1}{|c|}{ Soil property } & $\mathbf{2 0 0 6 / 2 0 0 7}$ & $\mathbf{2 0 0 7 / 2 0 0 8}$ \\
\hline Sand (\%) & 51.40 & 49.70 \\
Silt (\%) & 18.70 & 19.40 \\
Clay (\%) & 29.90 & 30.90 \\
\hline Soil texture & \multicolumn{2}{|c|}{ Sandy clay } \\
\hline Organic matter (\%) & 0.160 & 2.86 \\
Total N (\%) & 0.63 & 0.185 \\
EC(ds/m) (1:1) & 7.92 & 0.64 \\
PH(1:1) & \multicolumn{2}{|c|}{} \\
\hline
\end{tabular}

*According to Association of Official Analytical Chemists (A.O.A.C.) 1995.

Egypt. J. Agron. 38, No. 2 (2016) 
In this experiment, the twenty genotypes of covered, 2-rowed barley and two check cultivars, namely, Giza 127and Giza 128 were grown in field under three different irrigation regimes (Table 2) as :

1. Normal irrigation $\left(\mathrm{I}_{1}\right)$ : Every 10 days.

2. Moderate drought stress $\left(\mathrm{I}_{2}\right)$ : Two times irrigation and the next irrigation were withheld starting from the third one.

3. Severe drought stress $\left(I_{3}\right)$ : One time irrigation and the next two times irrigation was withhold starting from the third one.

TABLE 2. Irrigation regimes followed in the evaluation experiments.

\begin{tabular}{|c|c|c|c|c|c|c|c|c|c|c|c|c|}
\hline$\underset{\Xi}{\stackrel{\Xi}{\Xi}}$ & 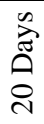 & 胥 & 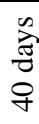 & 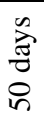 & 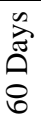 & $\sum_{\substack{0 \\
0}}^{\infty}$ & $\overbrace{\infty}^{\infty}$ & 竕 & 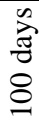 & 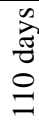 & 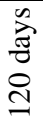 & 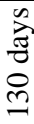 \\
\hline $\mathrm{I}_{1}$ & $*$ & $*$ & $*$ & $*$ & $*$ & $*$ & $*$ & $*$ & $*$ & $*$ & $*$ & $*$ \\
\hline $\mathrm{I}_{2}$ & $*$ & $*$ & - & $*$ & $*$ & - & $*$ & $*$ & - & $*$ & $*$ & - \\
\hline $\mathrm{I}_{3}$ & $*$ & - & - & $*$ & - & - & $*$ & - & - & $*$ & - & - \\
\hline
\end{tabular}

$*=$ Irrigation $\quad-=$ Skipping irrigation.

The studied characters in the evaluation experiment included days to heading, flag leaf area $\left(\mathrm{cm}^{2}\right)$, plant height $(\mathrm{cm})$, spike length $(\mathrm{cm})$, number of spikes $/ \mathrm{m}^{2}$, number of kernels/spike, 1000-kernel weight $(\mathrm{g})$ and grain yield (ardab/fad).

\section{Statistical analysis}

The separate as well as combined analysis of variance for different characters was done on a plot mean basis after testing for homogeneity of errors variance according to Gomez \& Gomez (1984). Revised Least Significant Difference (L.S.D.) at a significance level of 5\% was used to compare means according to Waller \& Duncan (1960). MSTAT_C (1991) computer software program was used to analysis of variance and Mean comparison of traits.

\section{Drought susceptibility index (DSI)}

Drought susceptibility index (DSI) was calculated for each genotype according to the method of Fischer \& Maurer (1978) as follows:

$\mathrm{SI}=\left(1-\left(\frac{Y d}{Y w}\right)\right) / D$

where;

$(\mathrm{Yd})=$ mean yield for genotype in stress environment.

$(\mathrm{Yw})=$ mean yield for genotype in normal environment.

$\mathrm{D}=$ environmental stress intensity which was calculated as:

$=$ mean of all genotypes in stress.

$=$ mean of all genotypes in normal environments. 
Genotypes with "SI" value of 1.0 or more than one are susceptible to drought, while those with values less than 1.0 are less susceptible and tolerant to drought.

\section{Results and Discussion}

Combined analysis of variance over the two years (Table 3) revealed that all studied traits were highly significantly affected by irrigation regimes and genotypes. Furthermore, the mean squares due to genotype $\mathrm{x}$ years, genotypes $\mathrm{x}$ irrigation regimes, years $\mathrm{x}$ irrigation regimes and genotypes $\mathrm{x}$ irrigation regimes $\mathrm{x}$ year's interaction were significant. These results indicated that barley genotypes behaved differently when they were exposed to different stresses, suggesting that it is essential to test genotypes under different environments in breeding program to identify the best genotypes suitable for particular environment. These results were also in line with those obtained by Atia et al. (1996), El-Seidy (1997), Kheiralla et al. (1997) and El-Koliey \& El-Hamid (2000).

\section{Morphological characteristics}

Days to heading

Under the third regime (severe drought), the average number of days to heading for the earliest genotype No. 7 was 65.00 days which was significantly less than the latest genotype, No. 8, by 13.00 days (Table 4). The percent of decrease in days to heading under severe drought for the earliest genotype, No. 7 and the latest one, No.8, (compared with normal irrigation ) as 19.75 and 13.00, respectively, with a general mean of $16.51 \pm 0.62$. The drought susceptibility index (DSI) of days to heading indicated that eleven genotypes had DSI <1 and were relatively tolerant to drought stress. The results indicated that days to heading were reduced by increasing drought stress. The differences in days to heading may be due to the increase in adaptation to drier environment in many crops which has been linked to earlier flowering (Turner, 1979). Earliness probably is the most efficient drought escape mechanism, especially when the crop is grown in a stored environment (Ceccarelli , 1986). These results were in accordance with those of El- Seidy (1997), Kheiralla et al. (1997) and El-Madidi et al. (2005).

\section{Flag leaf area $\left(\mathrm{cm}^{2}\right)$}

The average of flag leaf area for the highest genotype, No. 17 was $5.05 \mathrm{~cm}^{2}$ which was significantly higher than the lowest one, No. 3 , by $3.59 \mathrm{~cm}^{2}$, under severe drought (Table 4). The percent decrease under severe drought of flag leaf area for the highest genotype, No. 17 and the lowest one, No.3 due to drought increase were 61.89 and $84.23 \%$, respectively, with a general mean of $(71.52 \pm 1.35)$.

Drought susceptibility index of flag leaf area showed that six genotypes had a DSI $<1$ and were relatively tolerant to drought stress. It is of interest to note that most genotypes which have DSI less than one gave the least decrease in flag leaf area. Turner (1986) reported that drought avoidance involved rapid morphological development, leaf rolling, leaf shading, reducing leaf area, and increased stomata and cuticular resistance. These results are in agreement with those obtained by Lowlor et al. (1981), Andersen et al. (1992) and Essa (2003).

Egypt. J. Agron. 38, No. 2 (2016) 
EVALUATION OF TWENTY BARLEY GENOTYPES FOR DROUGHT ... 177

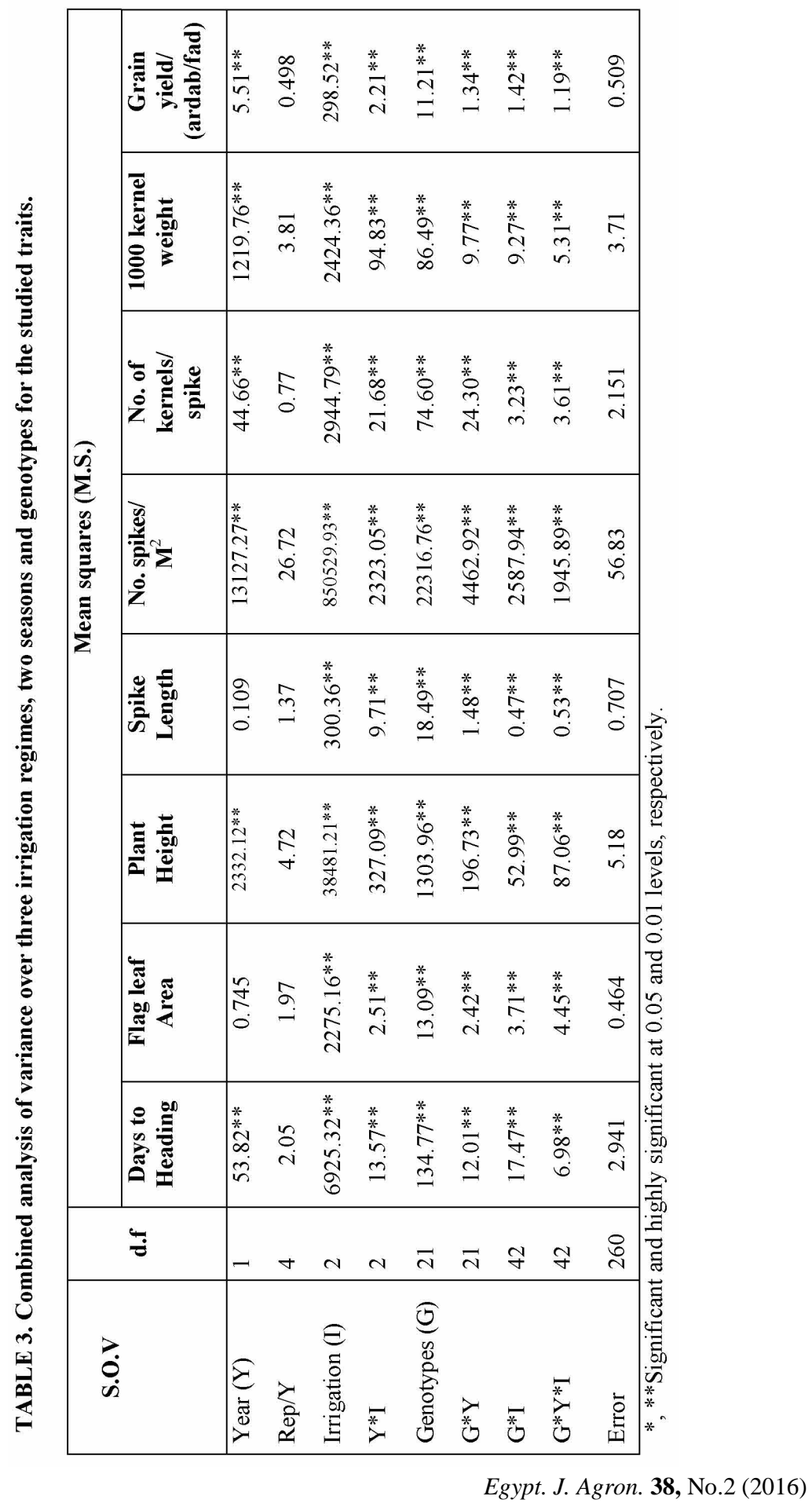


F.F.B. ABU-EL-LAIL et al.

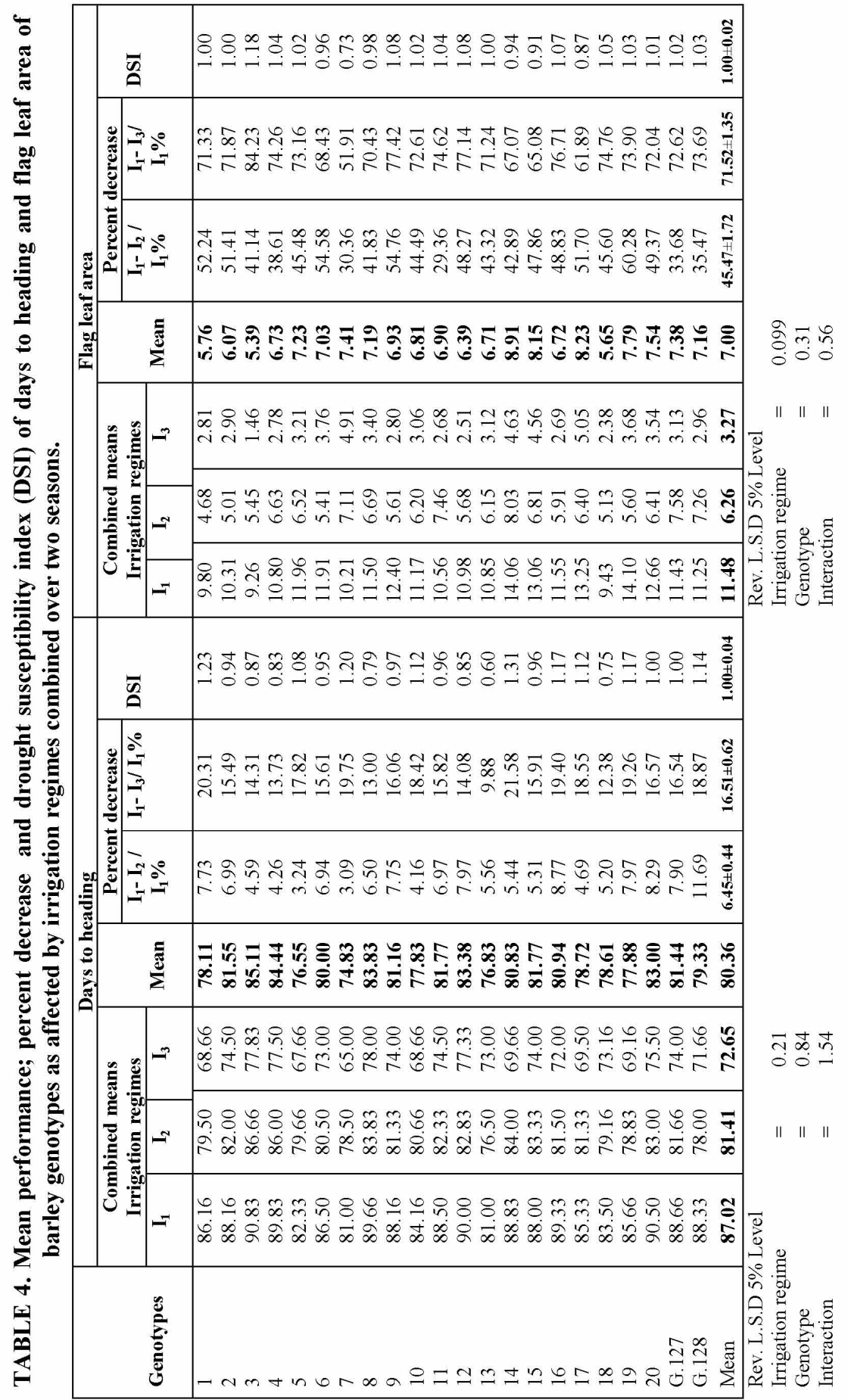

Egypt. J. Agron. 38, No. 2 (2016) 


\section{Plant height $(\mathrm{cm})$}

The tallest genotype under severe drought, No. 1 , was $84.00 \mathrm{~cm}$ tall, which was significantly higher than the shortest genotype, No. 11, by $26.17 \mathrm{~cm}$. (Table 5). The percent decrease of plant height under severe drought for the tallest genotype, No. 1 and the shortest one, No.11 due to drought increase were 32.26 and $34.28 \%$, respectively, with a general mean of $2.70+0.59$. Regarding DSI, nine genotypes had a DSI $<1$ and were relatively tolerant to drought stress. Plant height is reduced by water stress (Singh et al., 1986). A severe reduction in plant height is a common type of plant response to water stress in barley as reported by Ceccarelli (1986). These results are in line with those obtained by El-Seidy (1997), Gaspar et al. (1998) and El-Madidi et al. (2005).

\section{Spike length $(\mathrm{cm})$}

The longest genotype in spike length, No. 7 was $9.00 \mathrm{~cm}$ which was significantly higher than the shortest genotype, No. 4 , by $3.05 \mathrm{~cm}$ under severe drought (Table 5). The percent decrease of spike length for the longest genotype, No. 7 and the shortest one, No.4, due to drought increase were 31.90 and $32.40 \%$, respectively under severe drought, with a general average of $29.00 \pm 0.80$. Drought susceptibility index (DSI) based on spike length indicated that seven genotypes had a DSI $<1$ and were relatively tolerant to drought stress. It is of interest to note that increasing stress reduced spike length. Skipping irrigation at any stage reduced spike length (Kheiralla et al., 2004). These results are in harmony with those reported by Kheiralla et al. (1989), Gaspar et al. (1998) and Hamam \& Salman (2007).

\section{Yield and yield components}

Number of spikes $/ \mathrm{m}^{2}$

Under severe drought, the average number of spikes $/ \mathrm{m}^{2}$ for the highest genotype, No. 17 was 306.16 spikes which was significantly higher than the lowest genotype, No. 20, by 116.00 spikes (Table 6). The percent decrease in number of spikes $/ \mathrm{m}^{2}$, under severe drought, for the highest genotype, No. 17 and the lowest one, No.20 was 35.66 and $37.00 \%$ respectively, with a general mean of $40.64 \pm 1.64$, spikes $/ \mathrm{m}^{2}$. Results of (DSI) based on number of spikes $/ \mathrm{m}^{2}$ showed that nine genotypes had a DSI $<1$ and were relatively tolerant to drought stress. These results may be due to genetic variation. Generally, drought stress reduced number of spikes $/ \mathrm{m}^{2}$ by reducing number of tillers (Samarah, 2005). These results go in line with those reported by Tarred et al. (2002) and Hamam \& Salman (2007). 


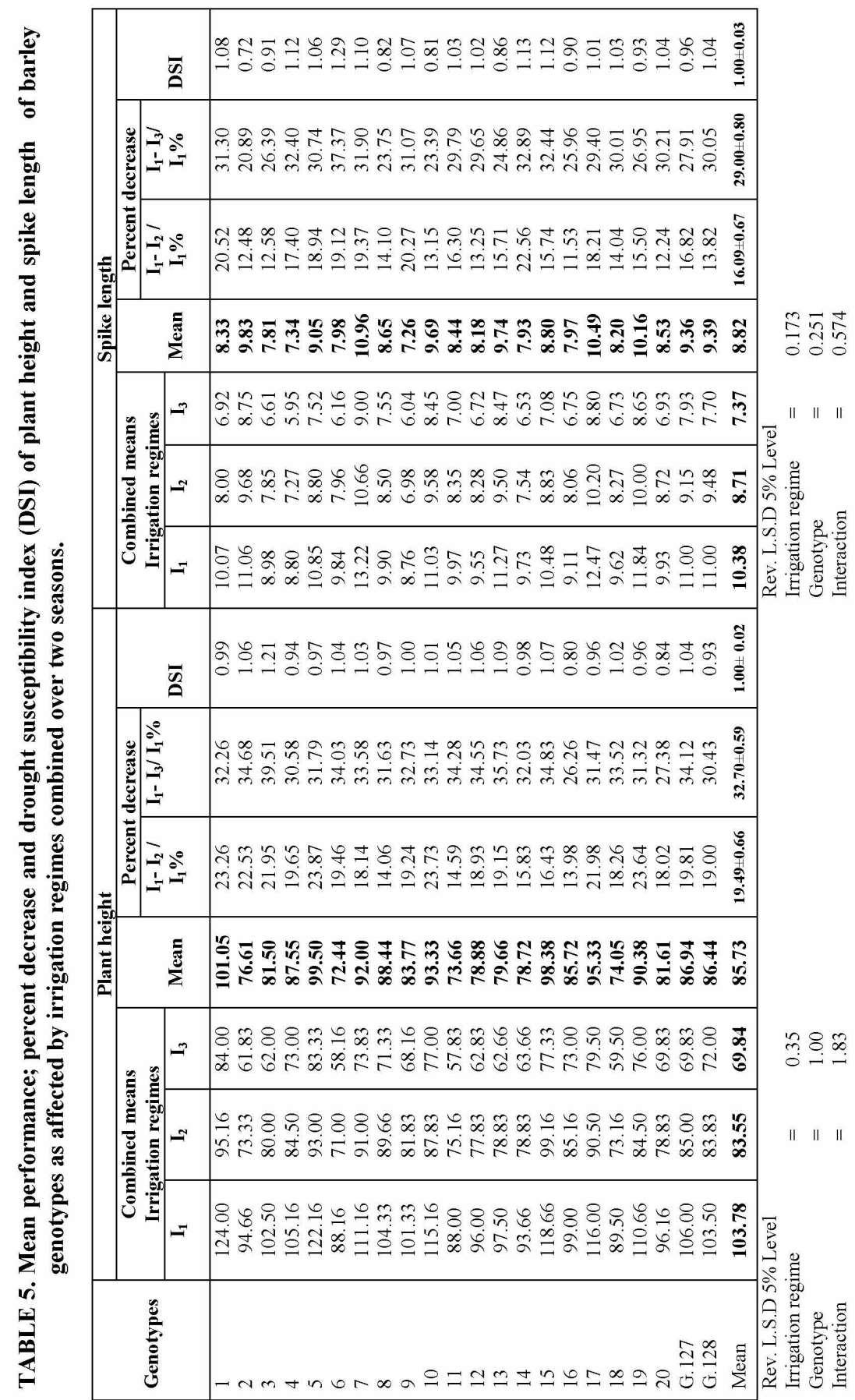

Egypt. J. Agron. 38, No. 2 (2016) 
EVALUATION OF TWENTY BARLEY GENOTYPES FOR DROUGHT ... 18

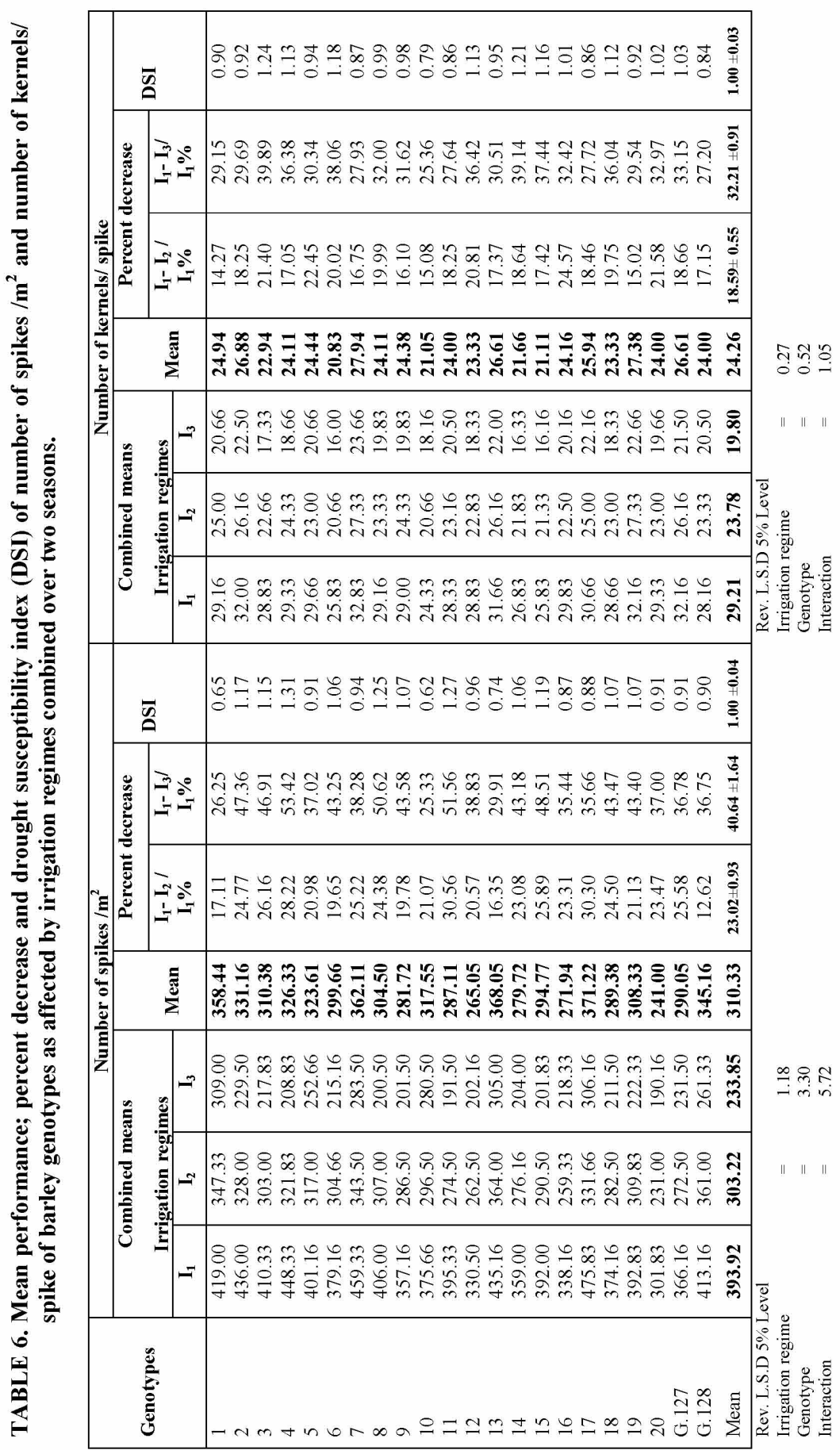

Egypt. J. Agron. 38, No.2 (2016) 
Number of kernels/spike

The highest average number of kernels/spike was 23.66 grains/spike for genotype, No. 7 which was significantly higher than the lowest genotype, No. 6 , by 7.66 grains under severe drought stresses (Table 6). The percent decrease in number of kernels/spike for the highest genotype, No. 7 and the lowest one, No. 6 due to drought increase was 27.93 and $38.06 \%$, respectively, with a general mean decrease of $32.21+0.91$, kernels /spike. Eleven genotypes had a DSI based on number of kernels/spike $<1$ and were relatively tolerant to drought stress. The reduction in number of kernels/spike by increasing drought stress may be due to the lack of water at tillering and or at flowering stage. Kheiralla et al. (1989) found that number of spikelets /spike decreased by skipping irrigation at any stage before flowering. These results are in line with those obtained by Andersen et al. (1992), El-Seidy (1997) and Hamam \& Salman (2007).

1000 - kernel weight $(g)$

The average of 1000 - kernel weight for the highest genotype, No. 17 was $43.23 \mathrm{~g}$ which was significantly higher than the lowest genotype, No. 15, by 7.63 g, under severe drought stress (Table 7). The percent decrease of 1000 - kernel weight under severe drought for the highest genotype, No. 17 and the lowest one, No.15 due to drought increase were 16.91 and $22.51 \%$, respectively, with a general mean of $17.70+0.84$, g. Regarding the drought susceptibility index of 1000 kernel weight indicated that eleven genotypes had a DSI $<1$ and were relatively tolerant to drought stress. The application of severe drought decreased grain weight and this may be due to water stress which reduced the final grain weight by curtailing the duration of the grain filling stage. Moisture stress applied just before or during the maturity process greatly reduced seed weight (Robins \& Domingo, 1962). These results were in accordance with those of Assey et al. (1990) and Samarah (2005).

\section{Grain yield (ardab/fad)}

Under severe drought, the average of grain yield (ardab/fad) for the highest genotype, No. 17 was $8.67 \mathrm{ardab} / \mathrm{fad}$, which was significantly higher than the lowest genotype, No. 9, by about $2.64 \mathrm{ardab} / \mathrm{fad}$ (Table 7). The percent decrease of grain yield for the highest genotype, No. 17 and the lowest one, No. 9 due to drought increase was 22.66 and $26.28 \%$, respectively, with a general mean decrease of $28.82+1.35$. Drought susceptibility index of grain yield ardab/fad indicated that the genotypes No. 10, 5 and 4 were the most tolerant of drought, which had DSI values of $0.69,0.74$ and 0.75 , respectively. The results showed that nine genotypes had a DSI based on grain yield $<1$ and were relatively tolerant to drought stress. A highly significant and negative correlation was obtained between the mean grain yield under severe drought stress and drought susceptibility index $\left(\mathrm{r}=-0.653^{* *}\right)$ (Buchner \& Frohberg, 1987). The yield reduction was much more severe if moisture stress occurred during and following heading, resulting in fewer heads, fewer spikelets /spike, and fewer kernels per spike (Robins \& Domingo, 1962). Severe drought stress at $20 \%$ field capacity until grain maturity reduced grain yield by reducing the number of tillers, spikes and grains per plant and individual grain weight (Samarah, 2005). These results go in line with those obtained by Kheiralla et al. (1997), Tarred et al. (2002), Motawei \& Abdalla (2003), El-Kholy et al. (2005) and Karami et al. (2005).

Egypt. J. Agron. 38, No. 2 (2016) 
EVALUATION OF TWENTY BARLEY GENOTYPES FOR DROUGHT ... 183

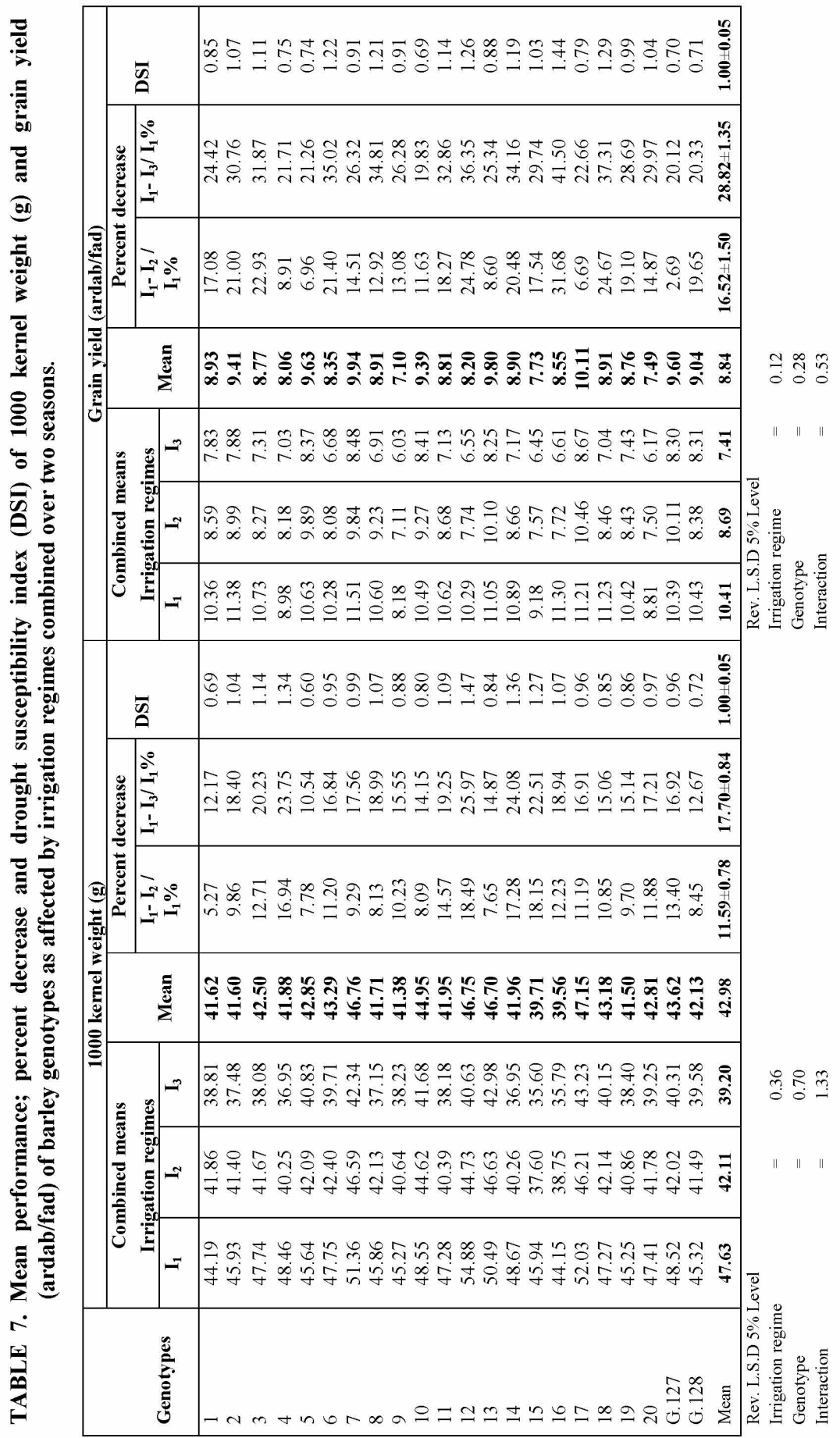




\section{Conclusion}

It is concluded from the results of this study that barley genotypes respond differentially to drought stress. The results indicated that five genotypes, No's 5, $7,10,13,17$ were tolerant to drought stress and had a DSI $<1$ for grain yield trait. In addition, severe drought stress reduced grain yield by reducing the number of spikes $/ \mathrm{m}^{2}$, number of kernels/spike and 1000-kernel weight compare results with performance under irrigated conditions. Yield components are the most important agronomic traits in selecting for genotypes tolerant to drought stress.

\section{References}

A.O.A.C. (1995) "Official Methods of Analysis", $16^{\text {th }} \mathrm{ed}$. Association of Official Analytical Chemists International, Arlington, Virginia, USA.

Andersen, M.N., Jensen, C.R. and Losch, R. (1992) The interaction effects of potassium and drought in field-grown barley. I- Yield, water-use efficiency and growth.Acta-Agriculturae-Scandinavica-Section-B, Soil and Plant Science, 42 (1), 3444 .

Assey, A.A., Saleh, M.E., Ramadan, I.E. and El-Sayed, A.A. (1990) Effect of irrigation and applying nitrogen on barley . Zagazig J. Agric. Res. 17 (3A), 613-622.

Atia, Z.M.A., Selim, A.H. and Moustafa, R.A.K. (1996) Evaluation of high yielding barley mutant with some local varieties and its response to different irrigation regimes and nitrogen fertilizer levels. Menofiya J. Agric. Res. 21 (6),1381-1402.

Buchner, P.L. and Frohberg, R.C. (1987) Stress tolerance and adaptation in spring wheat. Crop Sci. 27, 31-37.

Bulletin of the Agriculture Statistics (2014) Ministry of Agriculture and Land Reclamation Economic Affairs Sector, 28-29.

Ceccarelli, S. (1986) Tolerance to climatic stresses. Proceed. $5^{\text {th }}$ Int. Barley Genetic Symposium, Okayama 6-12 OCT.

Ceccarelli, S. (1987) Yield potential and drought tolerance of segregating populations of barley in contrasting environments. Euphytica, 36, 265-273.

Dorostkar, S., Paknyiat, H., Kordshooli, M.A., Ghorbani, R., Aliakbari, Sobhanian, N. and Valiloo, R. (2016) Evaluation of several drought tolerance criteria in cultivated varieties of barley (Hordeum vulgare L.) and their relationships with yield reduction. Science Research. 4( 2), 26-32.

El-Kholy, M.A., Gaballah, M.S., El-Ashry, S. and El-Bawab. A.M. (2005) Combating drought using yield stabilizing agents in barley. International J. Agric Biology. Pakistan, 7 (3), 369-375. 
El-Koliey, M.M. and El-Hami, M.A. (2000) Tolerance of some barley varieties to drought conditions. Assiut J. Agric. Sci. 31 (4), 247-267.

El-Madidi, S., Diani, Zineb and Aameur, F.B. (2005) Variation of agro-morphological characters in Moroccan barley landraces under near optimal and drought conditions. Genetic Resources and Crop Evolution.Kluwer Academic Publishers, Dordrecht, Netherlands: 52 (7), 831-838.

El-Seidy, E.H. (1997) Estimation of genetic effects for earliness and some agronomic traits in barley under water stress and non-stress condition. Annals. of Agric. Sci., Zagazig Univ., Egypt, 35 (3), 1147-1164.

El-Shouny, K.A., Mohamed, A.A., Farag, H.I. and Abo El-fotoh, Soad S. (2015) Performance and heterosis for yield, yield components and some physiological traits in barley under rain fed conditions at Maryout. Egypt. J. Plant Breed, 19 (3),185-207.

Essa, T.A. (2003) Evaluation of growth and dry matter production of cereal crops under severe drought stress. Annals. of Agric. Sci. Ain Shams Univ., Cairo, Egypt, 48 (1), 173-184.

Fischer, R.A. and Maurer, R.O. (1978) Drought resistance in spring wheat cultivars 1Grain yield responses. Aust. J. Agric. Res. 29, 897-912.

Gaspar, I., Zama, E. and Drobota, C. (1998) Modifications caused by weather stress in the morpho-productive elements of spring barley. Cercetari Agronomice in Moldova, $31(1 / 2), 67-71$.

Golbashy, M., Ebrahimi, M., Khorasani, S.K. and Choukan, R. (2010) Evaluation of drought tolerance of some corn (Zea mays L.) hybrids in Iran. African J. Agric. Res. $\mathbf{5}$, 2714-2719.

Gomez, K.A. and Gomez, A.A. (1984) "Statistical Procedures for Agriculture Researach". John Wiley and Sons. Inc. New York, Wiley-Interscience.

Hamam, K.A. and Salman, A.M.A. (2007) Evaluation of spring barley genotypes tolerance to drought stress and aphid infestation. Annals. Agric. Sci, Ain Shams Univ. Cairo, 52 (2), 327-340.

Karami, E., Ghannadha, M.R., Naghavi, M.R. and Mardi, M. (2005) An evaluation of drought resistance in barley. Iranian J. Agric. Sci. Fac. Agric, Univ of Tehran, Iran, 36 (3), 547-560.

Kheiralla, K.A., Bakhit, B.R. and Dawood, R.A. (1989) Response of wheat to drought conditions at different growth stages. Assiut J. Agric. Sci. 20, 161-175.

Kheiralla, K.A., El-Moreshidy, M.A., Motawea, M.H. and Saeid, A.A. (2004) Performance and stability of some wheat genotypes under normal and water stress conditions . Assiut J. Agric. Sci. 35, 74-94.

Kherialla, K.A., Ismail, A.A. and El-Nagar, G.R. (1997) Drought tolerance and stability of some spring wheat cultivars. Assiut J. Agric. Sci. 28, 75-88. 
Lawlor, D.W., Day, W., Johnston, A.E., Leg, B.J. and Parkins, K.J. (1981) Growth of spring barley under salinity and drought: Crop development photosynthesis, dry mater accumulation and nutrient content. J. Agric. Sci. Canb. 96, 167-189.

Mohammadi, M., Ceccarelli, S. and Naghavi, M.R. (2006) Variability and genetic parameters for related traits to drought tolerance in doubled haploid population of barley (Hordeum vulgare). International J. of Agric. and Biology. Pakistan, 8 (5), 694-697.

Motawei, M.I. and Abdalla, M.Y. (2003) Selection of resistance to Fusarium germinerum in barley under water stress by DNA markers. Alex. J. Agric. Res. 48 (1), 11-20.

Ramirez, V.P. and Kelly, J.D. (1998) Traits related to drought resistance in common bean. Euphytica, 99, 127-136.

Robins, J.S. and Domingo, C.E. (1962) Moisture and nitrogen effects on irrigated spring wheat. Agron. J. 54 (1), 135-138.

Samarah, N.H. (2005) Effects of drought stress on growth and yield of barley. Agron for Sustainable Development. EDP Sciences, Les Ulis, France, 25 (1), 145-149.

Shahryari, R. and Mollasadeghi, V. (2011) Introduction of two principle components for screening of wheat genotypes under end seasonal drought. Adv. Environ. Biol. 5 (3), 519-522.

Singh, N.P., Singh, S. and Murari, M. (1986) Response of barley to excess water application. Indian J. Agron. 31,165-171.

Tarred, A.M., Megahed, A.M. and Abdo, Fatmaa (2002) Effect of irrigation intervals on some physiological and yield traits of barley under sprinkler irrigation system. Zagazig J. Agric. Res. 29 (3), 877-890.

Turner, N.C. (1986) Adaptation to water deficits: A changing perspective. Aust.J. Plant Physiology, 13, 175-190.

Turner, N.C. (1979) Drought resistance and adaptation to water deficits in crop plants. In: "Stress Physiology in Crop Plants" (Mussell, H., R.C., Staples. Ed). pp. 343-372, New York, Willey. Interscience,.

Waller, R.A. and Duncan, D.B. (1960) Abays rule for the symmetric multiple comparison problems. Amer. State. Assoc. J. Des. 1458-1503. 


\section{تقييم عشرين تركيبا وراثيا من الثعير لتحمل الجفاف تحت ظروف التربة الرملية الطينية}

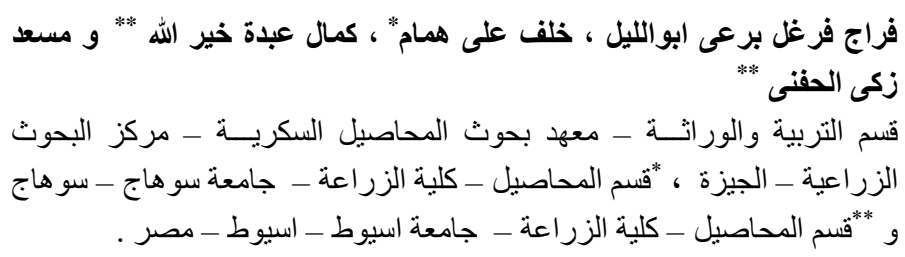

أجريت هذه الدراسة من أجل تحديد أفضل التر اكيب الور اثية و التى يمكن زر اعتها

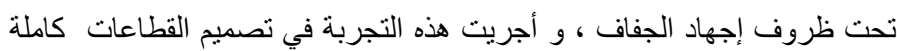

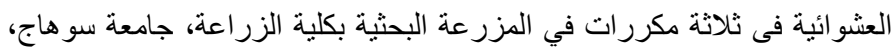

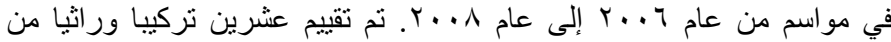

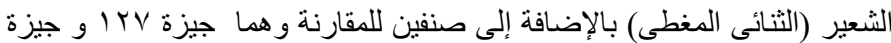

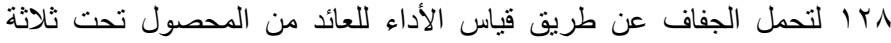

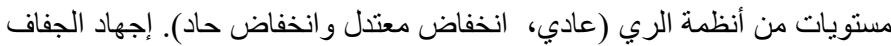

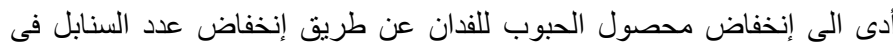

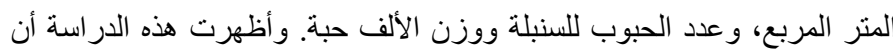

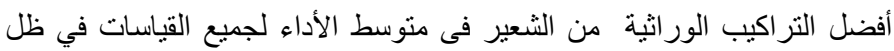

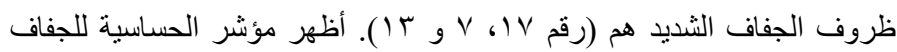

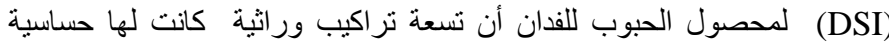

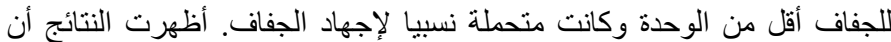

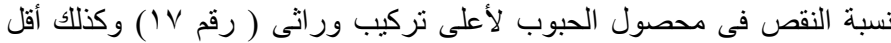

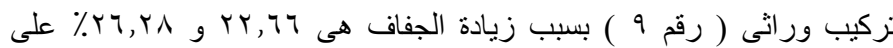

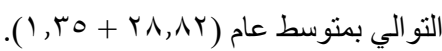

